\title{
Simulation of temperature at weld interface on friction welding
}

$\begin{array}{rlllll}\text { O学 } & \text { 吉岡顕二 } & \text { （姫路工大院） } & \text { 正 } & \text { 瀬尾健二 } & \text { （姫路工大） } \\ \text { 正 } & \text { 日下正広 } & \text { (姫路工大) } & \text { 正 } & \text { 木村真晃 } & \text { （姫路工大） } \\ \text { 正 } & \text { 富士明良 } & \text { (北見工大) } & & & \end{array}$

\author{
Kenji YOSHIOKA, Himeji Institute of Technology, Shosha 2167, Himeji-city, Hyogo-ken \\ Kenji SEO, Himeji Institute of Technology \\ Masahiro KUSAKA, Himeji Institute of Technology \\ Masaaki KIMURA, Himeji Institute of Technology \\ Akiyoshi FUJI, Kitami Institute of Technology, Kouen-chou 165, Kitami-city, Hokkaido
}

\begin{abstract}
This report describes the simulation of temperature at weld interface on friction welding. It was observed that the jointed region was occurred at the center portion on weld interface under the experiment. The simulation was noticed the yield stress at weld interface of specimen and made the model for the jointing mechanism. The analysis of temperature at weld interface was based on the jointing mechanism and applied two-dimensional unsteady-state conduction equation. The jointed region was occurred at the center portion so that the temperature of the center portion supplanted that of the periphery (outer surface) for yield stress depended on the temperature at weld interface. Comparing with the calculated and experiment values for the temperature at axial direction of specimen, it was approved that the slope of temperature coincided well. As a conclusion it is considered that the jointing mechanism was predicted by the simulation.
\end{abstract}

Key words : Friction welding, Temperature of weld faying surface, Jointing mechanism,

Two-dimension unsteady-state conduction equation, Yield stress, Friction torque.

\begin{abstract}
1. 错五
摩擦圧接法は, 摩擦推力のもとで被接合材の接合面 (以 下，圧接面)同士を回転接触させることにより摩擦熱を発 生させて接合を行う方法であり，各種産業分野で用いられ ている．その接合メカニズムは非常に複雑であり，明らか にされてはいない。このため, 実際に各種材料を組み合わ せて, 試行錯誤により接合条件を求めているのが現状であ り，良好な継手を得るための接合条件を理論的に確立する ことが求められている.また, 接合する試験片の物性值お よび圧接条件をパラメータとして, 圧接面温度の推定が可 能になると圧接条件の選定の指針になると考えられる。そ こで本研究では, 接合メカニズムをモデル化し, 試験片表 面からの放熱扔よび半径方向, 軸方向の熱伝導を考慮して 圧接面温度の解析を行った。 また, 軸方向の温度および摩 擦トルクを解析結果と実験結果とで比較検討した。
\end{abstract}

\section{2. 接合メカニズムのモデル化}

S15CK 同種材摩擦圧接では, 接合は圧接面中央部から 生じるものと推測されたので(1), 接合中の試験片の挙動を Fig.1のようにモデル化した。 まず，圧接面は(1)に示すよ うに軸心部を中心とした輪の集合と考えた。(1)は試験片同 士が接触した瞬間であり，圧接面では，(2)のように周速度 の速い外周部において発熱量が高くなり, 高温となる。こ こで, Fig.2 に示すように温度の上昇にともなって, 試験 片の耐力が低下する。 このため，圧接面では(3)のように外 周部における酎力が摩擦推力を下回り, 完全には受け持て なくなる，そこで，(4)のように高温部で受け持つことので きない推力分を内側の部分で受け持つこととなる。これは 摩擦推力が増加したと見なすことができ，急激に発熱量が 増加する. すると, (5)ように一つ内側の部分でも, 耐力 が摩擦推力を下回って, 受け持てなくなる.これら(2)〜(5) の状態が中心部まで絽り返され，6のように圧接面全体で 摩擦推力を受け持てなくなる。ここで, 外周部では周速度

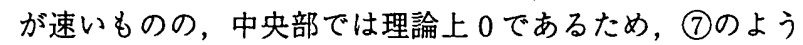

(1)

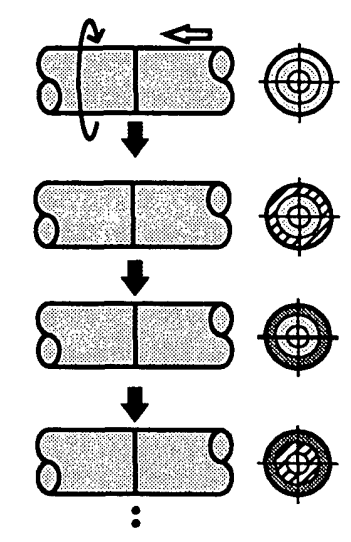

(5)

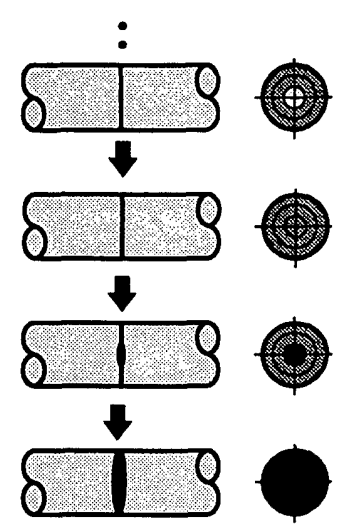

Fig.1 Schematic illustration of friction welding process.

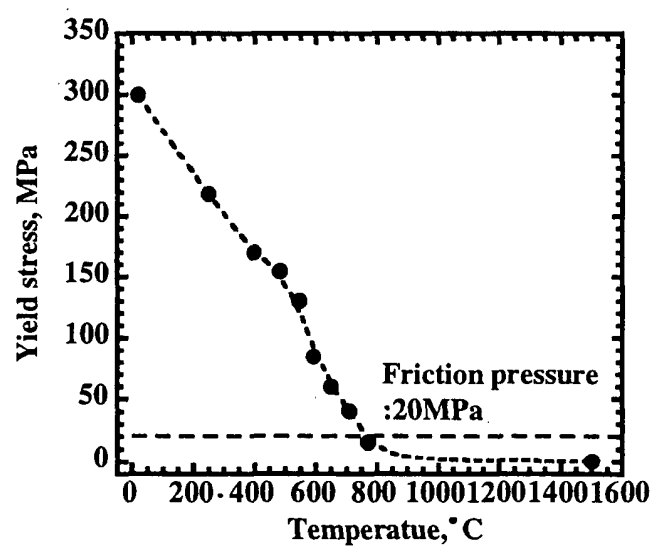

Fig.2 Relation temperature and yield stress of S15CK. 
に相対速度の少ない中央部から接合が生じる。この接合部 が外周部へと拡大し，最終的には(8)のように圧接面全体が 接合される．その後試験片はバリを排出しながら寄り始め ると考えられる。

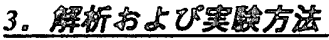

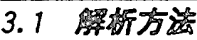

接合メカニズムのモデル化を考慮して，压接面の半径方 向と軸方向の温度について解析を行った。 そのために，発 熱を压接面での面熱源とし，試験片表面からの放熱および 半径方向，軸方向の熱伝導を考慮した二次元非定常熱伝導 方程式に，圧接面における熱的境界条件を用いて式(1)を 算出した.

$$
\begin{aligned}
T= & \sum_{n=1}^{\infty}\left(A_{n}+X_{n}\right) J_{0}\left(\alpha_{n} r\right) e^{-\alpha_{n} z} \\
& -\sum_{n=1}^{\infty} A_{n} J_{0}\left(\alpha_{n} r\right) \sum_{s=0}^{\infty} a_{n s} \cos \left(k_{s} z\right) e^{-\kappa\left(\alpha_{n}^{2}+k_{s}^{2}\right) t}
\end{aligned}
$$

ここで, $A_{n}, X_{n}, \alpha_{n}, k, a_{n}$ は係数, $r$ は圧接面の半径 $[\mathrm{m}], \kappa$ は温度伝導率 $\left[\mathrm{m}^{2} / \mathrm{s}\right], z$ は試験片軸方向の距離 $[\mathrm{m}], t$ は 摩擦時間 $[\mathrm{s}]$ である.

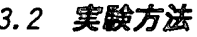

解析と比較を行うため，供試材にはモデル化した材料と 同じ S15CK 炭素鋼の丸棒を用い，旋盤により Fig.3のよう に加工し実験に供した。 また，固定側試験片は接合面から 軸方向に $5 \mathrm{~mm}, 10 \mathrm{~mm}, 15 \mathrm{~mm}$ の位置に $\phi 3.2 \mathrm{~mm}$ の穴を開 け， $\mathrm{R}$ 型熱電対を挿入して温度を測定した，摩擦圧接装置 は摩擦トルク測定装置を取り付けたブレーキ式摩擦圧接機 であり，実験において摩擦圧力を $20 \mathrm{MPa}$ ，摩擦速度を $27.5 \mathrm{~s}^{-1}$ (1650 rpm) と固定して接合を行った。また，接合中の摩擦 トルクならびに温度データを測定した。

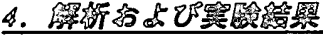

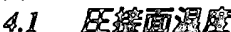

実験と同様の圧接条件を用いた圧接面半径方向の解析結 果を Fig.4 に示す．圧接面において温度は外周部から中央 部に向かって順に上昇していき，摩擦推力を受け持てなく なった瞬間に中央部の温度が急上昇する。このため，相対 速度の小さい中央部から接合が行われたと考えられる。そ の後, 温度は一定值に保たれるが, 外周部と中央部で差が 生じている．これは解析に扔いて，温度が融点に達すると 酎力が0になると考えているためである。

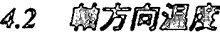

軸方向温度および摩擦トルクの解析結果と実験結果を Fig.5 (a)，(b)に示す。なお，Fig.5 (a)は解析結果，Fig.5 (b) は奏験結果である．摩擦トルクは (a)において時間の増加 にともなって $A$ から $B$ 点へ上昇し, 極大值に達した後, 急激に低下した。一方，(b)においても摩擦時間の増加に ともなって $A^{\prime}$ から $B^{\prime}$ 点へ増加し, 初期トルクに達した後, 低下した．試験片の様相観察では，初期トルク到達後に奇 り始めたので ${ }^{(1)}$ （a)の值は初期トルクと見なすことがで きる. 両者を比較すると, 初期トルクの值が解析と実験で 良く合っていることがわかる．また，解析では時間が増加 するにともなって温度は上昇し，軸方向の位置が圧接面か ら離れるにつれ，温度の上昇傾向は減少した。実験におい ても，摩擦時間の増加にともなって温度は上昇し，温度の 上昇傾向は解析と一致した。 以上より, 本研究の解析にお いて摩擦圧接継手の温度上昇が予測できると考えられる。

\section{5. 浣掼}

摩擦圧接継手における接合条件の選定の指針とするため に，接合メカニズムをモデル化し，温度解析を行った。そ の結果, 解析結果と実験結果は非常によく一致した。
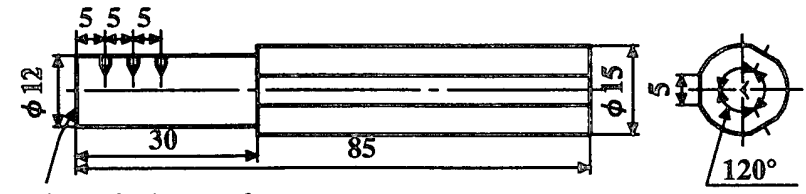

Weld faying surface (unit:mm)

Fig.3 Dimension and configuration of friction welding specimen.

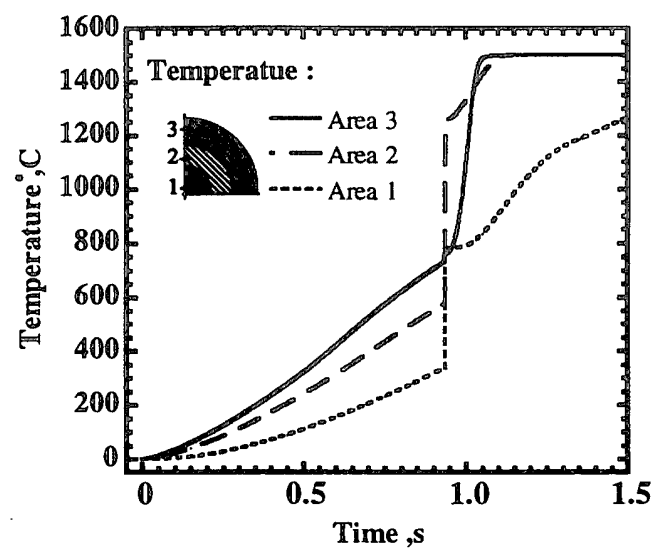

Fig.4 Calculated temperature at weld interface.

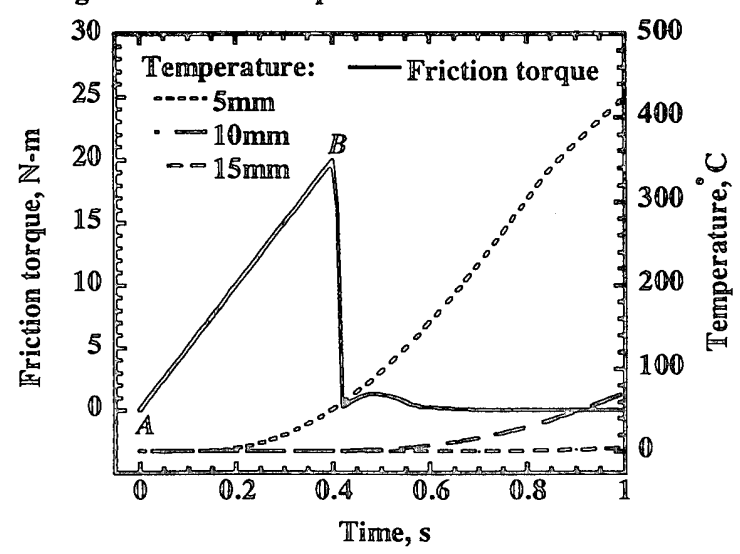

(a) Calculated value.

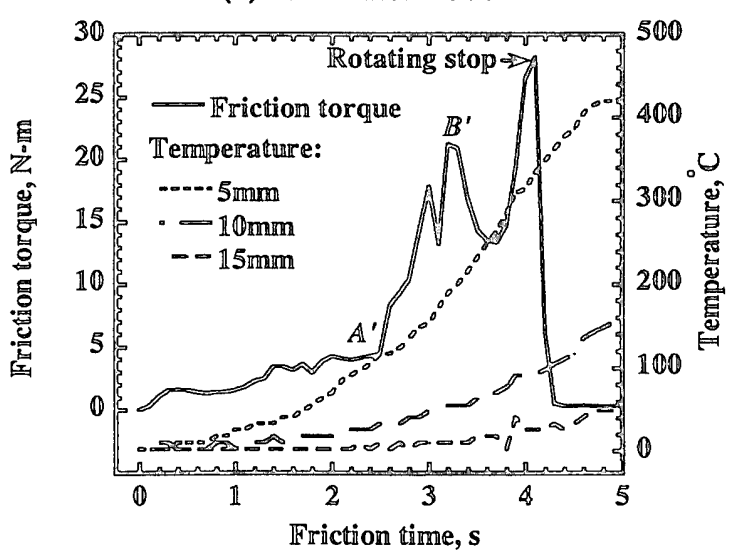

(b) Experiment value.

Fig.5 Temperature of axial direction.

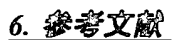

1)美王 他：S15CK 摩擦圧接継手における接合現象, 日本 機械学会関西支部第 256 回講演会講演論文集, 984-2 (1998)， 1-11 1-12 